\title{
PROF. DR. EFRASIYAP GEMALMAZ HAKKINDA SÖYLENENLER
}

Semra ALYLMAZ*

\begin{abstract}
. . . . 4 Uürkoloji dünyasında eski Türk dili, diyalektoloji, ve bilgisayarlı dil bilimi W. Walanında yazmış olduğu eserlerle ve yapmiş olduğu araşurma ve incelemelerle tanınan Prof. Dr. Efrasiyap GEMALMAZ, pek yakında emekliye aynlıp çalışmalann üniversite dişında sürdürmeye hazırlanıyor. Biz de, hocamız hakkında aile çevresinin, hocalarının, arkadaşlannın ve öğrencilerinin (çeşitli vesilelerle) söylemiş olduklanı sözleri, yapmış oldukları değenlendirmeleri bir araya getirip, onu bilinmeyen yönleriyle de tantmak istedik ${ }^{* *}$.

"Aile çevresinin ve yakınlannun Prof. Dr. Efrasiyap GEMALMAZ hakkında söylediklen" ve "Hocalarının, arkadaşlarının ve öğrencilerinin Prof. Dr. Efrasiyap GEMALMAZ hakkında söyledikleri" başlıklanı altunda dikkatlere sunmuş olduğımuz çalışmanın ilgi çekeceğine inanıyoruz:
\end{abstract}

\section{Aile çevresinin ve yakunlarının Prof. Dr. Efrasiyap GEMALMAZ} hakkında söyledikleri:

Inci GEMALMAZ (Eşi): Efrasiyap Bey'i bir eş olarak kabul edip evlenmemde kişiliği, dürüstlüğü ve çalışkanlığı çok etkili oldu. $O$, gerçekten mükemmel bir eş; iyiliksever, hoşgörülü bir insan; çalışkan, üretken, başarılı bir bilim adamıdır. O'nun hayatta elde ettiği her şeyi hak ettiğine inanyorum.

Ayşe GEMALMAZ (Kız1): Efrasiyap GEMALMAZ'in kizı olduğum için çok şanslyyım. Bisiklet binmeyi, bilgisayar kullanmayı, araba kullanmayı ve daha pek çok şeyi babam öğretti. Babam son derece hoşgörülü bir insandır. Hiç bir konuda baskı yaptuğını haturlamıyorum. Babam hiçbir zaman seçimimize karışmazdı. Bizi yönlendirir; neyi nasıl yapmamız gerektiğini anlaturd. Onu dinlemediğimiz zamanlar bazen üzücü sonuçlar yaşardık. O zaman bile "Ben size söylemiştim." demezdi. Çocukken edebiyat ve dilbilgisi ödevlerimizi yapmasını isterdik; ama asla

\footnotetext{
* Atatürk Üniversitesi Kâzım Karabekir Eğitim Fakültesi Türkçe Egitimi Bölümü

** Bu çalışmayı hazırlarken Yard. Doç. Dr. Cengiz ALYILMAZ tarafindan Tuba ŞiMŞEK'e hazirlatılan "Meslek Hayatınin 35. Yllinda Prof. Dr. Efrasiyap GEMALMAZ (Basimamis Lisans Tezi, Erzurum, 1999)" adlı çalışmadan da yararlandım. Yard. Doç. Dr. Cengiz ALYILMAZ'a ve Tuba ŞiMŞEK'e bu vesileyle teşekkulr ederim.
} 
yaptıramazdık. Kelimelerin anlamını sorduğumuzda da sözlükten bakarak bulmamızı isterdi. O, bize sorumluluklarmizı bilmeyi ve hayatta hakederek kazanmayı öğretti. Babamun örnek aldığım bir diğer yanı da hiçbir işte yllmamasıdır. Ben babamın "Olmuyor, olmayacak!" dediğini hiç duymadım. O evde daha çok bir arkadaş gibidir. Babam, benim için kırılması ve üzülmesinden en çok korktuğum arkadaşımdır. Onu, evden uzaklaşıp farklı aile ortamlarında yetişmiş insanlat tanıyınca daha çok anladım ve daha çok sevdim.

Emre GEMALMAZ (Oğlu): İyi bir baba, iyi bir yol gösterici, iyi bir arkadaş... Başka ne söyleyebilirim ki?

Prof. Dr. Ersan GEMALMAZ (Kardeşi): Ağabeyim düşünce ufku geniş biridir. Belli prensipleri vardir. Kendisini ilgilendirmeyen meselelere asla karışmaz. Ancak elinden her türlü iş gelir. Çok esprili bir kişiliğe sahiptir. Bir araya gelince daha çok son teknolojik gelişmelerden ve bilgisayarla ilgili konulardan bahsederiz.

Togay GEMALMAZ (Amcasının oğlu): Efrasiyap son derece sıradışı bir insandir. Onun sıradışliğı benim için en ön planda olan unsurdur. Onun kendine ait dünyasında bir şeyler üretmek gibi tasavvurlan vardı. Fakat ben İstanbul'da elektrik ve elektronikle ilgili bir fakülteye gittim. $O$, da Ankara'da Türkolojiye gitti. Bu tercihi ilgi alanının ve sevdiği şeylerin çok dışında gözüküyor; ama dilin insan hayatında ve cemiyette önemli bir unsur olduğunu tespit ettiği için böyle bir tercih yaptı sanıyorum. $O$, şu an kendi sahasında da çok güzel işler yapmış, başarilı bir ilim adamı olmuştur. Ancak fitratında yer alan bir yetenek olduğunu düşündüğüm teknolojik alanda tahsilini devam ettirseydi, bu sahada ilme çok güzel şeyler vereceğine ve yalntz Türkiye'de değil dünya genelinde isim yapacağına eminim. Ama hayattaki tesadüfler insanın yaratulısıına göre firsatlar vermeyebiliyor.

\section{Hocalannın, arkadaşlannın ve öğrencilerinin Prof. Dr. Efrasiyap GEMALMAZ hakkinda söyledikleri:}

Prof. Dr. Orhan OKAY: Efrasiyap GEMALMAZ benim üniversitedeki hocalığımın ilk öğrencilerinden biridir. Onun her zaman olağanüstü bir dil öğrenme kabiliyeti vardı. Genel lenguistik'i iyi kavramış olduğu için kendisine yabancı olan bir dile ait bir ibareyi siyak u sibak yardımıyla çözebiliyordu. Erzurum ağızlanı üzerine hazırladı̆̆ı ve üç büyük cilt hacmindeki doktora tezinin, benzer konulardaki çalışmalara kıyasla üstünlüğü, bu alanın uzmanlarınca daha iyi takdir edilir. Türkoloji kongrelerinde çok farklı ve çok dikkate şayan tebliğler verdiğini de biliyorum. Kendisine emanet edilen genç dilci adaylarıyla, büyük bir ciddîyetle ilgilenmiş, her birinin yüksek lisans ve doktora çalışmalanım ortaya çıkması için büyük gayret göstermiştir. Onun, Atatürk Üniversitesi'nde bir takım elektronik aletleri bilgisayarların her çeşidini ilk kullanan değilse bile ilk kullananlardan biri olduğu muhakkaktır. Bunda ilmî tecessüsün, dolayısıyla teknik aletlere merakın rolï kadar, hep o ilk tanıyışımda koyduğum teşhisin, yani gülmek, yani hayat bir oyun telakki etmek mizacının rolü vardır. Bu, yaşı zannederim altmışa yaklaşan ve her 
zaman safiyeti ve hayata bakışı ile çocuk kalabilen insanın o elektronik aletleri de birer oyuncak gibi, ama en karmaşı ilimleri kolaylaştıracak bir oyuncak gibi gördüğünü zannediyorum. Bu ak saçlı profesörü, o aletlerle meşgul olưken görecek hangi çocuk, Tanpınar'ın Acıbademdeki Köşk hikâyesindeki kahraman gibi, "omuzuna yavaşça elini koyup 'sevgili dayıcığım, beraber oynasak olmaz mi?" demez acaba? Efrasiyap'ı hep, Vâsıf'in o meşhur şarkısındaki "Mihneti kendine zevk etmektir âlemde hüner" misraryla beraber daha çok Fïkret'in "Hayata neş'e güneştir" misraryla haturlayacağım.

Prof. Dr. Sebahattin GÜLLÜLÜ Efrasiyap ile 1950'li yallardan beri, kark küsur yıldır tanışıyoruz. Bizirn fakültemiz için bölüm farkı o kadar önemli değildir. Kişilerin birbirleriyle uyumlu olabilmesi önemlidir. Meselâ ayn bölümde olup da arkadaş olmayan pek çok kişi vardır. Bunun yanısıra bu arkadaşlığımuzda Erzurumlu olmamızın rolü vardır. Ailelerimizin tanışıor olmasının da aynı şekilde. Onun ailesi de Erzurum'un köklü ailelerindendir; benim ailem de öyle. Eşinin hem benim eşimle hem de benimle sinıftan arkadaş olmamız da dostluğumuzun oluşmasındaki etkenler. Bunun dişında tabî̀ "espri uyumu" söz konusu. Efrasiyap, sıra dışı bazı tutumların, sıra dışı bazı düşüncelerin sahibidir, olağanüstü derecede zekidir. Bunun yanısıra son derece duygulu bir insandır. Bir şeyin gayri ciddî olan yanını keşfedebilmesi ve o gayri ciddî olan yanı insanları kırmadan ortaya koyabilmesi önemli bir özelliğidir. Çok önemli yetenekleri vardır. Bilgisayan bizim üniversitemizde ilk kullanan kişidir. Edebiyatçı olmasına rağmen elektronik alanda ilginç şeyler yapard. Efrasiyap her şeyden önce alanında bağırmayan, ulaşmış olduğu düzeyi bağıra bağıra ifade etmeyen, ama şu an 'Türkiye'de alanındaki en yetkili adamdır. Efrasiyap zamanın boşa geçirmez. Her çalışmasının altında bir üretim vardır. Çok başarılı bir akademisyendir. Fevkalâde gelişmiş bir yabancı dil bilgisi vardır. Yurt dışında, yabancı bir ülkede hocalık yapabilmiş nadir arkadaşlarımızdandır. Çok gelenekçi bir arkadaştır. Gelenekçiliği de çok sevimlidir. Yirmi yaşına varmış bir arabası vardır. Ben onu bir arkadaşı gibi sevdiğini fark ediyorum. Gelenekçi oluşunun yanında çok çağdaş bir arkadaştur. Zaten Efrasiyap'ın ailesi "GEMALMAZLAR" çok değişik bir ailedir. Oradaki tüm gençler şimdi önemli yerlerde olabilmişlerdir. Ama en ilginçleri de bence Efrasiyap'tur. Efrasiyap ile yaşadığım her şey unutulmaz bir anı olmuştur. Bir gün arkadaşlarla oturuyorduk. Büyükşehir Belediye Başkanı olan kardeşi Ersan Bey radyoda Erzurumlular'a soba yakma usulünü anlatyordu. Efrasiyap dinledi sonra "Bunlan nereden öğrenmiş şaşıyorum. Bizim evde sobayı yakan bendim; 1sınan o idi." demişti. 20. yüzyılın Nasrettin Hocası olarak bir profesör nasıl olabilirse o da öyledir. Efrasiyap gibiler bulundukları yerlerin tadıdirlar. Herhangi bir nedenle uzaklaştukları zaman o yerde tupkı bir hava kaybı, su kaybı, oksijen kaybı söz konusu olur.

Prof. Dr. Hüseyin AYAN: Efrasiyap GEMALMAZ'ı bir arkadaşı, aile dostu olarak yakından tanıdım. Efrasiyap'ın mükemmel bir hafizası vardır. Lâkin dünyanın yanmışında, yıkılmışında pek alâkası olmayan bir tavır sergiler. Gözlem 
kabiliyeti mükemmeldir. Hadiseleri iyi takti eder. Milletlerin özelliklerini de çok iyi bilir. Dünya meselelerine bîgâne değildir. Ama şu ana kadar hangi partiye oy verdiğini bilmem... Son derece geniş bir dünya görüşü vardır. Meseleleri hakkıyla kavrar ve pünüzsüz demokrasi taraftarıdır. Efrasiyap, bir meseleye kafasını taktı̆ı zaman günlerce çalışırdı. Gerekirse masasında uyur, ama çözüme ulaşturmadan kalkmazdı. Sadece edebiyat ve dil meseleleriyle uğraşmı̧̧ bir insan değildir. Bir elektronikçi kadar bu bahisleri bilir. Efrasiyap çok samimidir. Asla aldatmaz ve yanıltmaz; görüşlerinde asla bir art niyet yoktur. İster dostu olsun, ister düşmanı her zaman doğru bildiğini söyler. Bizim dostluğumuzun bu kadar köklü olmasının nedeni de budur.

Prof. Dr. Saim SAKAOĞLU Efrasiyap Bey'i Fransa'dan Atatürk Üniversitesi'ne döndüğü yll tanıdım. Ailece dost olup birbirimize gidip gelmeye başladık. Kader beni dokuz yıl onunla aynı odayı paylaşmakla mükâfatlandırdı. Hakikaten bu benim için bir mutluluktu. Efrasiyap Bey'in benim üzerimde yer etmiş en çarpıcı yanı bir gün elindeki elektronik dergisiyle odaya girip "Bu benim makalem" demesi olmuştu. Efrasiyap Bey dil doktoru olmakla beraber, elektronik bilgisi olan biriydi. Yakın zamana kadar bütün Türkiye'de üniversite hocaları kendilerine verilen boş listelere öğrenci adlarını yazarak doldururlar ve idareye teslim ederlerdi. Efrasiyap Bey öyle değildi. Efrasiyap Bey devletten önce bilgisayara geçen belki Türkiye'nin ilk hocasıdır. $O$ henüz bilgisayarn adın bile anan yokken, kendi evindeki bilgisayarıyla öğrenci notlannı yazar; bilgi sayar çıkışı listeler hazırlard. Efrasiyap Bey, iki eli kanda olsa kendisinden istenen bir yardımı geri çevirmezdi. Meselâ doçentlik tezimi hazırlayıp daktilo etmiştim ve bir dilci gözüyle bir de kendisinin okumasını istemiştim. Efrasiyap Bey, büyük bir sabırla baştan sona okudu. Benim gözümden kaçan bir takum teknik hatalan liste hâlinde bana vermişti. Nitekim ben de şu an arkadaşlann bakmamı istedikleri yazllan, Efrasiyap Bey'i haturlayarak geri çevirmemeye özen gösteriyorum. Efrasiyap GEMALMAZ, iyi bir ilim adami olmakla beraber ilmi de pek ciddiye almaz. Yaptuğ zaman en iyisini yapard, ancak olmasa da olur gözüyle bakardı. Meselâ doçentlik tezinin dönüşü onu doçentlikten vazgeçirme noktasına getirmişti. Oysa $\mathrm{ki}$, sadece ek kök meseleleri ile uğtaşan adamların profesör olduğu bir dünyada Efrasiyap Bey'in yeni düşünce ve buluşları onu çoktan profesör yapmaliyd. Onun ek bilgisi ile ilgili bir kitapçı̆̆ı vardı ki, bana göre o bile alanunda başı başına bir yeniliktir. Efrasiyap Bey hiç belli etmez; ama duygusal bir insandır. Daha doğrusu duygusallığını gizlemeye çalışan bir kişidir. Esprili ve hayat girgira alan yanı olmasaydı, duygusallığ daha çok ön plana çıardı. Belki de bu duygusalluğ gizlemek için böyle bir tavir sergiliyor.

Prof. Dr. Ahmet Bican ERCILASUN Efrasiyap Bey'i Erzurum'daki asistanlık yllarımızdan beri tanıyorum. Efrasiyap Bey ile ilişkimiz meslektaşlı̆̆ın ötesinde bir dostluğa dayanıyor. Efrasiyap Bey'in başka insanlara zarar verecek hiç bir yanı yoktur. Onda başka insanlara kötülük yapacak hiç bir şey bulamazsınız. Efrasiyap Bey, son derece iyi bir bilim adamidur. O'nun özellikle Erzurum 
ağızlanyla ilgili çalışması konuyla ilgili herkes için müracaat eseri niteliği taşımaktadır. Efrasiyap Bey, benim "Gülnar" adlr romanımda da "Alper", ismiyle yer alur.

Prof. Dr. Kemal YAVUZ: Efrasiyap GEMALMAZ'1, 1978 ylindan beri tantyorum. $\mathrm{O}$, öğrenmeye ve öğretmeye doymayan çok iyi bir bilim adamıdır. Türkçe'nin bilgisayarlara uyarlanması ile ilgili son derece ciddî çalışmaları vardır. Efrasiyap Bey, prensiplerine sıkı sıkıya bağlıdır. Çok dürüsttür verdiği sözden de asla dönmez.

Prof. Dr. Yavuz AKPINAR: Efrasiyap Bey'i sanurum Fransa'dan dönmesinden sonta tanidım. IJer halde ben o zaman fakülteyi bitirmiştim, kütüphanede çalışıyordum. Şimdi tam olarak haturlayamıyorum. Aradan çok zaman geçti. Onu, sanki kendimi bildiğimden beri tantyormuş gibiyim. Aslinda o, benim için her zaman Erzurum'daydı. Erzurum'u, orada birçoğumuzun yetiştiği Türk Dili ve Edebiyat Bölümü'nü, onsuz düşünemiyorum bile.

Bana göre Efrasiyap Ağabey, kurulduğu günden beri bu bölümün temel taşlatından biri olmuş Şinasi Tekin, Selahattin Olcay, Kaya Bilgegil, Niyazi Aku. Haluk İpekten, Hüseyin Ayan, Orhan Okay, Gönül Alpay, Mehmet Akalın, Muhan Bali, Bilge Seyidoğlu, Harun Tolasa, Saim Sakaoğlu gibi hocalarımızın, ağabeylerimizin başında gelir. Bütün bu hocalar, Erzurum'da Türk Dili ve Edebiyatı Bölümü'nü kuran, oraya sağlam bir temel atan rahmetli hocalarmız Ahmet Caferoğlu ve Mehmet Kaplan Beyler'in açtŭ̆ yolda başartyla yürüyüp bu bölümü Türkiye'nin en iyi öğtetim kurumlarından biri hâline getirdiler.

$\mathrm{Bu}$ grup içerisinde bilgisinin derinliği ölçüsünde alçak gönüllülüğüyle, öğrencilerine, dostlanına gösterdiği yakın ilgi ve yardımseverliğiyle Efrasyap Ağabey'in özel bir yeri vardır. $O$, öğrencilerinin asla unutmadıklan bir yol göstericidir.

Diştan bakınca memleket meselelerine pek ilgi göstermiyor gibi görünmesine rağmen, $o$, tam bir aydın sorumluluğu ile hareket eder. Onun söylediği her sözde, yaptığı her işte bu sorumluluğu hissedersiniz. Bazen yarı şaka, yarı ciddî söylediği sözler, ylllar sonra öyle bir yerde, öyle bir konumda aklınıza gelir, zihninizden bir şimşek gibi çakıp geçer ki, asıl o zaman ne dediğini anlarsınız. "Geri kalmışlık bir bütündür, parçalanamaz!" gibi...

Onun rahat konuşmaları, şuh sohbetleri kendisini iyi tanımayanları aldatabilir: Bu dı̧̧an rahat görünen insanın kendi bilim dalında çok önemli eserler vermiş, orijinal fikirler sahibi biri olduğu pek anlaşllmaz. Hatta öğrencileri ve meslektaşları arasında bile onu ancak yıllar sonra -o da şöyle böyle- anlayanlar aa değildir!

Efrasyap Ağabcy, Fransa'da kaldığı süre içinde ilk nesil bilgisayarlarla ilişki kurmuş, yaratulıştan gelen zekasıyla; bir edebiyatçıdan, dilciden hiç de beklenmeyen 
mükemmel matematik - mantk bilgisiyle; Fransa'da bizzat tanıdığı Guiraud ve eserlerini okuduğu Saussure gibi bilim adamlannm etkisiyle, belki de Türkloji dünyasında ilk defa dilbilim problemlerinin içine girmiş, Türk diline modem dilbilim açısından bakmaya başlamıştı.

Mükemmel Fransızcası, rahatça okuyup anladı̆̆ İngilizce, Almanca ve takip edebildiği Rusça'sıyla; hocası Şinasi Tekin Bey'in de katkı ve etkisiyle iyice vakıf olduğu Köktürk ve Uygur dönemi Türkçesi'ylc, Efrasiyap Ağabey, bilimsel araşturmalarına, çok az dilcinin ulaşabileceği bir birikimle başlamıştr; fakat hiç de ummadığı ve asla hakketmediği tavirlarla, engellerle karşılaştu!

Hocası Şinasi Tekin'in -birçok kimseye malum sebeplerle- Amerika'ya gitmesiyle birlikte, son safhasina getirip tamamladiğ Uygurca bir metin olan "Tişastvustik" hakkındaki doktora tezi ortada kaldı! Yeni doktora tezi danışmanı Prof. Dr. Selahattin Olcay Bey, "Eski Türk Dili" metinleri üzerinde uzman olmadığını ileri sürerek, Efrasiyap Bey'den yeni bir tez hazırlamasını istedi! Tamamlanmış tezi mecburen bir tarafa birakan Efrasiyap Bey, kendini uzun ve yorucu bir araşturmanı̀n içinde buldu; çünkü onun anlayışında "bir işi yüzeysel, zevahiri kurtaracak tarzda yapma" diye bir düşünceye yer yoktu. Böylece sanurım 56 yıldan fazla süren ciddî ve titiz bir çalışmayla "ikinci doktora tezi"ni hazurladı. Günümüzde en iyi diyalektoloji araşturmalanndan biri olarak kabul edilen "Erzurum İli Ağızlañ" işte böylece ortaya çıktı; ama onun çilesi henüz bitmemişti!

Hiç unutmam, Fransa'dan döndükten sonra TÜBİTAK'a belki de büyük ümitler ve beklentilerle Türkçe'nin bilgisayarlarda kullanımı hakkında, zamanına göre oldukça ileri ve orijinal bir proje teklif etmişti. Aldığı cevap "Böyle bir şey olmaz!" yolunda, bu kurumun bilimsel haysiyetine gölge düşürür nitelikteydi! Simdi, aradan yaklaşık 25-30 yil geçtikten sonra bu kurumun aynı konuda araşturmalar yapması için Efrasiyap Bey'e teklifte bulunduğunu işittim! Güler misin ağlar misin?!

Bunlar yetmiyormuş gibi Efrasyap Bey'in ayağı bir de doçentlik tezi aşamasında taşa değdi. $O$ zaman tezini inceleyen jüridekiler -sözün doğtusu tezin mahiyetini iyice anlayamadıklan için- olumsuz rapor yazdılar! $O$ zamana kadar karşısına çıkan engellere belki de "kaderin bir cilvesidir" diyen Efrasiyap Ağabey, bu darbe karşısında artık eski tevekkülünü koruyamamıștı! Bit bilim adamı olarak mutlaka son derecede alınmış, onuru incinmişti; ama bunu hiçbir zaman, hiçbir kimseye açıç̧a ifade etmedi; sadece reddedilen bu doçentlik tezini 1982'de basturdığında, tezi için yazılan raporları eserinin sonuna eklemekle yetindi: Anlayana sivrisinek saz...

Bütün bunlara rağmen o, öğrencileriyle her zaman candan ilgilenmiş, onlara daima yol göstermiş, ellerinden tutmuştur, kendisine zaman zaman saygısızca davransalar da -hatta bir iki açıkgöz, onun bazı görüşlerini, yazılatunı, eserlerini kendi mallanymıs gibi bastunp sahiplenseler bile- Efrasiyap Bey, bunlara "çalmışsa 
da miri malı çalmış" kabilinden hiç aldırış etmemiş, sadece ince bir alayla gülüp geçmiştir. Bu taviı onun "Erzurumlu" yanıyla ilgilidir.

Efrasiyap Bey'in, bilim adamlığ yanında çok belirgin bir "Erzurumlu" hüviyeti de vardır $\mathrm{ki}$, şimdi birçok Erzurumlu dahi bunun ne olduğunu pek bilmez: Birçoğunun bildiği, anladığı Erzurumluluk, sadece sett, delikanlı tavırlı "dadaş"lıktır. Halbuki Efrasiyap Bey, temsilcisi artık iyice azalmış şehirli, okumuş Erzurumluyu temsil eder. $\mathrm{O}$ entellektuiel olgunluğuyla birlikte mahallî kimliğini "Erzurumluluğunu" da her zaman korumuştur; hatta âlimliğinden kolay kolay hiç söz etmediği hâlde, bu "Erzurumlu" kimliğiyle zaman zaman açıkça övünür de. Diğer yandan Erzurumluların artık terk edilmesi gereken bazı tavıtiarını, kat kanaatlerini açık açık alaya almaktan da hiç çekinmez. Onun bu konuda anlattığı hikâyeler, latifeler hiç unutulmayacak cinstendir.

Efrasiyap Ağabey, ülkemizde bilgisayan ilk kullananlardandır. Yapuklanyla asla övünmez; sürekli bir şeyler üretir ve öğretir. Türkoloji dünyasının kendisini geç keşfetmesinde, anlaşılamamasının, Erzurum gibi gözden uzak bir muhitte bulunmasinun rolü büyüktür.

Her şeye rağmen biliyorum ki, o zihnen emekliye ayrılacak bir insan değildir. Bu yüzden de kendisine daha nice ylliar sağlkkla, mutlulukla araştırı yazma imkânı vermesi için Tantriya dua ediyorum.

Prof. Dr. Recep TOPARLI: Zamanın birinde bir hoca ile çalıskan bir öğrencisi varmıs. Öğrenci derslerde hocasına sürekli soru sorduğu için hoca da geceleri mum 1şı̆̆ında çalışarak onun muhtemel sorularına hazırlanurmıș. Bir gün yine böyle çalışırken mumun sönük alevleri hocanın yorganının yanmasına neden olmuş. Yullar geçmiş. Öğrenci hocasının hatırını sormak için onun evine gelerek kapıyı çalmış. Kapıyı hocanın hanımı açmış ve kim olduğunu sorunca öğrenci kendisini tanıtmış. Hocanın hanımı ona; "Yaa! Sen hocanın yorganımı yaktıran kara molla mısın?" diye serzenişte bulunmuş.

Saygideğer Hocam Prof. Dr. Efrasiyap GEMALMAZ, her hâlde kendisine çok soru sormamdan olacak bu, yorganı yaktıran kara molla lakabını bana uygun görmüştï. Ylllatın Türk Dili'ne adayıp benim de bu sahada çalışmama ön ayak olan Hocam's kelimelerle anlatmak o kadar zor ki.

Y1l 1972, Atatürk Üniversitesi Edebiyat Fakültesi Türk Dili ve Edebiyatı Bölümü’nü kazanarak lisans öğrenimine başladığım zaman tanıdım değetli hocamı. Bana Türk Dili'ni o sevdirdi, bilim adamı olmam için elinden geleni o yaptı. Beni çok severdi. Asistan olarak göreve başladığım 1977 yulından Tokat Gaziosmanpaşa Universitesi'ne atandığım 1993 yuluna kadarki bilimsel hayatumda yantmda bana en büyük destek olarak o vardı. Bilimsel basamaklara takılmadan çıkmamdaki rolü inkâr edilemez. Beni bir öğtencisi değil de evladı gibi severdi. Bu sevgisini her 
zaman ortaya koyar ve herkese de anlaturd. Sürekli gülümseyen tavrrlan, ince ve keskin zekâsı, yardımseverliği, bilimsel disiplini zihinlerden asla çıkanlamayacak özelliklerinden yalnızca birkaçıdır. Kötülük, kötü düşünce onun kalbinde hiçbir zaman yer bulamamıştır.

1993 yılinda Erzurum'dan ayrilmamı çok zor kabullendi. Her zaman sağ kolum diye nitelendirdiği bir öğrencisinden ayrulmak ona çok zor gelmişti. Gerçekten ben de onun sağ koluydum. Her zaman onun yanında olurdum ve ondan bir şeyler öğrenerek hayat üniversitesinde başaril olmaya çalışırdım. Sürekli gülümseyerek yaptığı esprilerde ince nükteler gizliydi. Güldürürken, düşündüren espriler yapardi. Erzurum'dan ayrildı̆̆ın 1993 yulından bugüne kadar yine bana yardımcı oldu. Başım sıkıştı̆̆ı, zorda kaldığım zaman hep ona başvutdum. Bundan sonra da başvurmaya devam edeceğim. Hocam'a yeni hayatunda sağlık ve mutlulukla geçireceği uzun ömür diliyor ve saygyla ellerinden öpüyorum. Bende hakkın büyük, hakkını helâl et saygıdeğer hocam...

Prof. Dr. Leyla KARAHAN: Anadolu ağızlannin siniflandırimasına yönelik çalışmalarım sırasında bu alanda yap̧ılmış pek çok eser inceledim. Bu eserleri karşılaşurma firsatı buldum. "Erzurum İli Ağızları" çok farklıydı. "Neden benzerleri az?" diye çok düşünmüşümdür. Sabır, disiplin, titizlik ve ilim aşkı... Böyle bir eserin mayasında bunlar bulunabilirdi ancak. Bu yüzden Efrasiyap Bey'den çok etkilendim. İlim adamı olarak benim için iyi bir örnek olmuştu. Kendisini çok sonraları tanıdım. Tevazu, herkese yakışı; ilim adamına daha çok yakışır. Tevazunun bir ilim adamını nasıl "büyük" yaptı̆ı̆ı Efrasiyap Bey'de gördüm. Türkoloji, kendisinden daha çok çalışmalar bekliyor.

Prof. Dr. Meşedihanım NIMET: Türkoloji'nin her daliyla ilgilenmiş olan büyük bilim adam Efrasiyap GEMALMAZ:dan Türkoloji dünyasının yeterince yararlanamadığına inanıyorum.

Prof. Dr. Valeh HACILAR: Efrasiyap Bey'i önce yazlarindan; sonra da şahsen tanıdım. İlmî nezaketiyle; nezaketi ilmiyle yarışan bir insan. Onu tanımak büyük mutluluk ve aytıcalik...

Doç. Dr. Turgut KARABEY: Prof. Dr. Efrasiyap GEMALMAZ'1, öğrencilik yullarumda Fransa'da olduğu için tanıyamamıştum. 'Tanıyan eski ögrenciler, renkli bir şahsiyet olduğunu söylerlerdi. Daha sonra ayn bölümde öğretim üyesi olup çalışmaya başlayınca yakından tanıma imkânı buldum.

Efrasiyap Bey, oturmuş bir ders anlatma ve öğretme tekniğine sahip değerli bir hoca. Kendi alanıyla ilgili yurt içi ve yurt dışı yayınları, yakından takip eden bir bilim adam. Mesleğinin haysiyetini koruyan, onu makam, mevki ve çıkarından üstün tutan biri. Verdiği karar kendince doğruysa, kim gelirse gelsin, araya kim girerse girsin ondan vazgeçmeyen, adil bir karaktere sahip biri. Çok zeki ve o kadar da saf ve temiz. Bu iki özelliğ in onda nasıl bir arada bulunduğuna hayret ederim. İnsanların hepsiyle iyi geçinen ve onlara elinden gelen yardımı esirgemeyen bir 
insan. Bildiklerini herkesle paylaşan, onlara bıkmadan ve usanmadan her defasında anlatmaktan çekinmeyen değerli bir öğretici. Ülkemizde her kademede böyle insanlara ihtiyacımız var. Çevresine neşe ve şefkat saçan, onlan incitmeyen, birlik ve beraberliğe yönlendiren biri. Meselelere daimâ mizah açısından bakar, onlanı ciddîye almaz. Sanurum bunun sebebi, Türkiye'nin sosyal yapisından kaynaklanmaktadir.

Doç. Dr. Orhan YAVUZ Hocam Efrasiyap GEMALMAZ'1 1975 ylinda, Erzurum'a öğrenci olarak gittiğim günden beri tanırım. Öğrencilik yıllarım boyunca derslerimize girdi. Türkiye Türkçesi'ni, Göktürk, Uygur, Karahanl 'Türkçeleri'ni, Çağdaş Türk Lehçeleri'ni hep ondan öğrendik. 1980 yllindan sonra da asistanı oldum. Efrasiyap Bey, çok çabuk farkedilecek bir içtenliğe sahiptir. Dürüstlüğü onu tanyan herkes tarafından bilinir. Efrasiyap Bey için özetle şunu söyleyebilirim: Öğrencilerinin sunav kağıtlan ondan her zaman tam puan almasa $\mathrm{da}, \mathrm{o}$, öğrencilerinden, bir hoca, bir arkadaş ve bir insan olarak hep tam puan almıştur.

Doç. Dr. Metin AKKUŞ: Bir bilim adamı olarak Efrasiyap GEMALMAZ adını her hâlde ilk defa dil derslerimizden duymuş olmalıyım. Çok belirgin bir hatarlama değil bu. Selçuk Üniversitesi'nde, bölüm dersleri için on beş günde bir Ankara'dan gelen hocalarmuz arasinda Prof. Dr. Hasan EREN de vardı. Ders konusunu Yakutça ve Çuvaş̧̧a için ayırmış olan EREN Hoca, Türk dilinin ağız, şive ve lehçe problemlerinden bahsederken sıkça Anadolu ağızlatıyla ilgili atıflarda bulunurdu. $\mathrm{Bu}$ atflar arasında GEMALMAZ Hoca'nun Erzurum ağzı ile ilgili eserinin de yer almış olacağını ilgilileri tahmin edeceklerdir.

İkinci sınıfta geçirdiğim bir ameliyat nedeniyle, Selçuk Üniversitesi'ndeki derslerimi aksatmamak için yatay geçişle Atatürk Üniversitesi'ne kaydımı yaptırdığım zaman, öğıtetim yılının ikinci yarısı tamamlanmak üzereydi. Derslere başlayamadığım için henüz tanışma firsatı bulamadığım sınıf arkadaşlarımdan edindiğim ders notları arasında GEMALMAZ Hoca'nin Azerî Türkçesi ile ilgili olanlar da vardı. Malûm oklama sistemine göre işlenmiş olan ders notlan fazlasıyla ilgimi çekmişti. Ders notlanını ve sistemle ilgili örnekleri hastanedeki yatağımda kavradım ve zihnimde yeni bir aydınlık pencere açlmış olduğunun hazzını yaşadığımı hatırlıyorum. Daha sonraki yıllarda fakültede alınan kararlar sonucu dil derslerimizde bir çeşitlilik oluşmuştu. Bunlar içerisinde o dönemde GEMALMAZ Hoca'nin verdiği Cağdas Türk Lebceleri benim Konya'da Hasan EREN Hoca'dan aldığım Türk Dilinin Lebfeleri dersinin konulanyla birleşti. Bundan sonta ben Türk dilinin lehçelerine hiç kayıtsız kalmadım, edebiyat alanında kendimi geliştirmeye çalışmama rağmen Türk dili ve lehçeleri bana hep yakın bir dost kapısı gibi ilgimin devamlilığını sağladı. Hoca'nın oklama sisteminin, yıllar geçtikten sonta, üniversitede öğrenci ders icmallerini hazırlarken bilgisayar program dilinin içinde yer aldığını; eksik bir parantezin bir programı nasıl aksatabileceğini gördüğüm andaki şaşkınlık ve eğitimciye/hocama minnet duygularumı hâlâ öğxencilerimle paylaşıııın. 
GEMALMAZ Hocam'la ilgili söz söyleyecekler arasında kendime hak vermemin asıl nedeni meslek hayatıma başladığım ilk gün, onun hocam olma sıfađna bir yenisinin daha eklenmesidir. Oda arkadashğgz demek haddim değil. Ama kendisiyle oda paylasım konusunda bana verilen firsat, benim için hocam daha yakından tanıma şansıydı. Araştırma Görevlisi olarak göreve başladığım ilk gün (15 Ocak 1985), o dönemde bölüm başkanı olan merhum Hocam Prof. Dr. Halûk IPEKTEN, odasından benimle beraber çıktı ve fakülte öğretim elemanlannın bulunduğu bölümün alt kat merdivenlerinin hemen bitimine rastlayan odaya beraber girdik. Odada Efrasiyap GEMALMAZ Hocam vardı. Bundan böyle bir süre kendisiyle beraber oturacaktum. Yani Hocam odasını benimle paylaşacaktı. $O$ günün şartlañnda bunun gönüllü bir kabulleniş olup olmadığ konusunda bir fikrim yoktu. Hâlen de bunu bilmiyorum. Ancak kendime oda arkadashl̆ğ sifatını yakışturamamam nedeniyle onun odasını paylaşan biri olarak daha çiçeği burnunda bilim adamlığına ilk adımlarını atan benim için hocanın kişiliği bulunmaz kaftanmıș!... Bunu ancak yillar sonta hocalik konumu kazanup asistanlarımla olan ilişkilerimi gözden geçirme firsatım olduğ̆ zaman daha iyi anladırn. Burada IPEKTEN Hocam'in benim için hazırladığı bir çok imkân gibi, ben farkında olmadan bana sağladığ bu ilk şans için şüktan duygularımı ifade etmeden geçemeyeceğim.

Efrasiyap GEMALMAZ Hoca, gerçekten benim için bir şanstı. Ancak bunu akademisyenler arasındaki ilişkileri bütün ayrıntılaryla öğrendikten sonra fark edebildiğimi itiraf etmeliyim. $O$ günün şartlarını şimdi değerlendirerek daha iyi anlayabiliyorum. Daha ilk gününün acemiliklerini ve hatalannı ancak GEMALMAZ Hoca gibi bir kişiliğin bir sünger gibi yok edebileceğini şimdi anlyorum. Bu aynı zamanda benim için bir çıraklık tezgahıyd. Elbette kendisiyle olan oda paylaşımı konusunda geleneksel çizginin sinurlanını aşmadığımı düşünüyorum. Kendine karşı biletek bir saygısızlıkta bulunmamın da benim kişiliğimle bağdaşmayacağını söyleyebilitim. Ancak yine de hocanın her şeye karşı, benim şimdi aşırı karşıladığım bosgörüsü̈, mutlaka o dönemde hoca-öğrenci ilişkimizin hoca-meslektaş ilişkisini kurmada bir geçiş ve köprü dönemi oluşturduğunu ibretle gözlemliyorum.

Dönemin şartları gereği, bir süre sonra Hocam GEMALMAZ, bölümden aynlan Turgut ACAR Bey'in odasına geçti. GEMALMAZ Hoca'nun yakın dostu ACAR'la odaları yan yanaydı. Odada ben kaldım. Hoca yan odaya geçti, ancak bu defa komşuluk ilişkilerimiz hoca-öğrenci saygı ve sevgisine zarar gelmeden devam etti. Ancak bunun benim katkulanmdan çok, görgü ve tecrübesinin yanı sıra sevecenlik ve hoşgörü çizgisinden biç aynilmamış olan Hocam'in başanısı olduğunu düşünüyorum. Çünkü Hoca ikbal endişelerinden kendini uzaklaştrrmış görünür. Bu nedenle odasının şartlan çok uygun olmadığı hâlde diğer meslektaşlarının aksine bunu bir problem hâline getirmeyecek bir kişilik sergiler. Komşuluk mesafemiz daha sonraki oda düzenlemelerinde farkllaş̧t. Ancak Hocam'la olan diyalog çizgimiz hep olumlu yönde gelişti ve -bana göre- daha sağlam zemine oturdu. 
Sevecenlik, hayatun hep gülünç yönlerini ön plana çıkarş̧, gerçekte çok önemsediği hâlde olup bitenlerden etkilenmemiş gibi görünmek; sonucu alınmasa da hep değişimden ve yenilikten yana olma; kabullerin kıriłmasına ironik yaklașımları mutlaka bana da bir şeyler vermiş olmalıdır. Bugün bölümümdeki meslektaşlantm başta olmak üzere çevremdekilerle her ne pahasına olursa olsun diyalogu kesmeme tavrumin, kendi kişiliğimle uyum sağlayan Hocam'dan, bir yönüyle bilinç altuna yerleşmiş, öğrenilmiş bir tavir olabileceğini düşünüyorum. Kendisiyle ilgili bir çok aytinttyı hatırlamak mümkün. Ancak bundan fazlası sözü uzatmak olur. Eminim, diğer meslektaşlannın, yakınlarının, öğrencilerinin, dost ve arkadaşlarından her birinin hatırlayacaklan arasında hocanın kişilik çizgileri ortaya çıkacaktır. İnanyorum ki, bütün çizgiler birleştirildiğinde onun portresi, genel hatlarıla, olumlu çizgilerden oluşacaktur.

Meslek hayaunda belli bir süreyi geride burakmış olanlarımız için bir şeyler söylemek gelenek hâline geldi. Ancak hakkında güzel şeyler düşünmediğiniz biri için bir şeyler yazmak bana ters gelir. Hocam GEMALMAZ hakkında bir hos sadanın geride kalmasını arzu ettim. Çünkü onunla ilgili zihnimde kalanlar güzelliklerdir. Birilerine iyilikle kendini yad ettirmek her birimizin başarabileceği şeylerden değildir. Meslek hayatındaki ümitlerini, arzu ve hayallerini ne kadar gerçekleştirdi, bilemiyorum. Ancak kendisinin olmadığı zaman ve mekânlarda iyilikleriyle anulabilmek yaşam tahtasına çizilmiş en kalın ve kalıcı çizgilerden biri olmalıdır. GEMALMAZ Hoca bizim yaşamımızda böyle kalıcı bir çizgi olarak kalacak. Hangi zaman ve zeminde olursa olsun "GEMALMAZ" adlandirmasinin hafizamdaki adı buydu, büyük ölçüde böyle kalacağını ümit ediyorum.

Doç. Dr. Zikri TURAN: Prof. Dr. Efrasiyap GEMALMAZ'la, ilk defa bir ögrencisi olarak karş̧laşum. Fakültede, bütün sınıf arkadaşlanım gibi ben de, daha onun derslerinin kendisiyle tanışmadan, seleflerimizin "oklama" dediği, şöhreti ile tanıştım. Sonra, dilimizin yapısını, fonksiyon-anlam-sözdizimi ilişkisini belirten oklu ve sıfir morfemli, fiil ve isim kategorilerini işaretleyen artli eksili vb. ifadelerle açıklamaya ve izah etmeye çalışan purnl purıl bir beyinle karşı karşıya olduğumuzu anlayanlardan oldum. Verdikleri, malûmat yığın değildi. Ufkumuzu açıcı, anahtar bilgiler veriyordu. İlmin bir formül, bir denklem eksenli bilgilenme ve araşturma yolu olduğunu anlamanın ilk tohumlarınin atıldığ dersler arasindaki payınun, aslan payı olduğunu söylemem gerekir. Sonraki yllar, her vesileyle, kanaatlerimi pekiştirmiștir. Eğer Türkçe gibi bir diliniz varsa, Efrasiyap GEMALMAZ gibi dilci ilim adamlarınizin olmasi gerekir.

Yard. Doç. Dr. Avni GÖZÜTOK: Hocam'in kendine has bir konuşma tarzı var. Onun bilmi gibi konuşması da yüksek perdedendir. O'nun bu özelliği kibirinden değil, aşır derecede hassas, samimi ve heyecanlı oluşundan kaynaklanmaktadır. Ögrencisi sınava girse onun yerine Hoca heyecanlanır; endişelenir. 
Yard. Doç. Dr. Kâzım KÖKTEKIN: Hocam, Prof. Dr. Efrasiyap GEMAIMAZ çok yönlü ve çok özellikli bir insan. Bir insan ve akademisyende olması gereken pek çok özelliği kendisinde taşıdığına her zaman inanmışımdır. Onun kişisel ve bilimsel özelliğinin birkaç cümleye suğdırlabileceğini düşünmüyorum. Bana göre $o$, geleceği görebilen, insanlan seven ve insanlara hoşgörülü davranan, kimseyi kırmak istemeyen, herkesin iyjliğini düşünen, bat ve doğu kültürünü kendisinde birleştiren, çağdaşığı ve bilimselliği büyük ölçüde yakalamış, hepsinden önemlisi fedakâr bir insan. Bir hoşgörü ve bilgelik abidesi. Bunlar, yaklaşık 18 yıldır tanıdığım hocamın bende bıraktığı izlenimlerin birkaç tanesi. Başka ne diyeyim. Bence o, insan gibi insan, hoca gibi hoca...

Yard. Doç. Dr. Cevdet ŞANLI: 1982 yilunda Atatürk Üniversitesi FenEdebiyat Fakültesi Türk Dili ve Edebiyatt Bölümü öğrencisi olduğumuzda bölümü ve hocalanmızı yeni yeni tanıyorduk. İkinci sınıfa geçince Eski Türkçe dersi ile birlikte dersin hocası Efrasiyap GEMALMAZ'ı da tanıma imkânı bulduk. O zamanın şartlan içinde anlayamadığımız, ancak mesleğe atıldığımızda fark ettiğimiz Hoca'nın Türkçe'yi tupkı matematik formülleri gibi bir formüller manzumesine oturtup, Türkçe'nin sistematiğini her seviyede kavratabilme gayesini, sadece biz ögrencileri değil; genel manada Türkiye Türkolojisi, yıllar sonra anlayabilecektir. Sonuç itibaryyla Türkiye Türkolojisi geç de olsa Efrasiyap GEMALMAZ'ı fark edebilmiş ve kavrama yönünde adum atabilmişse ne mutlu...

Öğr. Gör. Kadir YÜCEL Onu çok uzun yillardır tanıyorum. Hatta belirli bir tarih söyleyemeyecek kadar uzun zamandır tanyorum. Efrasiyap'ın bilimsel yönünü konuşmak benim haddime düşmez. Bir dost, bir arkadaş olarak onun hakkında birşeyler söyleyeceğim: Efrasiyap, çok dürüst bir insandır. Hiçbir zaman kişiliğinden ödün vermedi. Birtakım insanlar vatdır, oyunu kurallarnna göre oynarlar ve kişiliklerinden ödün verirler. Efrasiyap sahip olduğu kariyeri bilgisi ve çalış̧masıyla almış ender insanlardandır. $\mathrm{O}$, onurunu herşeyin üzerinde tutar. Hiçbir zaman ikbal peşinde koşmaz. Bazılanında eksik olmayan makam hưsının Efrasiyap'ta öne çıktığın hiç görmedim. Bazıları "Ben falan kişiyim bana şöyle önem verilsin, böyle davranılsın" diye beklenti içindedirler. Efrasiyap ise, her zaman bu gibi şeyleri alaya almış, dalga geçmiştir. $O$ kendisine zorla saygı duyulan insanlardan değildir.

Uz. Feyyaz tBRAHtMHAKKIOĞLU: Efrasiyap Bey ile biz ayn mahallenin çocuklatıydık. Dolayısıyla ailece tanışırdık. Çok dürüst ve temiz bir ailenin çocuğudur. Onun ailesi, çevrede oldukça sevilen, kapılatı rahatça çalınabilen cömert, gönlü zengin bir aileydi. Efrasiyap Bey de işte böyle bir ortamda yețşmiş̧tir. Efrasiyap Bey'in kabına sığmayan bir zekâsı vardır. Bir dost, bir arkadaş, bir hemşehri olarak ondan çok şey ögrendiğime inanyonum.

Muammer AKPINAR: Ben Türkiyat Araştırmalanı Enstitüsü sekreteriyim. Efrasiyap Bey, yaklaşık on ylddır enstitümüzün müdürlüğünü yürütmektedir. Feragat ve özverinin en iyi ömekleri ondadır. Yapılan iyi bir işten dolayı tebrik 
edilse, "Onu ben değil; sekteter veya diğer arkadaşlar yapti" diyerek kendi başarılarını da başkasına mal eder. Bununla ilgili yüzlerce hatıradan birisi şöyledir. Bilgisayarlar konusundaki bilgisi herkes tarafindan bilinen Hoca'yla birlikte Enstitümüz'le ilgili bir işi takip için bir fakülteye gittik. Burada etrafumızı çevirdiler. Herkes bilgisayar programlar hakkında bir şeyler sonuyor; Hoca ise sürekli anlattyordu. Artuk kendi işimizi unutmuştuk. Bu durum yaklaşık üç-dört saat sürdü. Daha da uzayacaktı ki, ben devreye girdim: "Hocam öğle yemeğini kaçırdık, bari saat 14.00'te yapilacak Yönetim Kurulu toplantisına yetişelim" dedim. Hoca, 'Tamam' dedi ve biraz sonra oradan ayrlldık. Sanki bilgisayar öğrenmeye gitmişiz ve de hoca onlardan bir şeyler öğrenmiş gibi yolda bana: "Görüyor musun? Bunların çoğu benim öğrencim, şimdi bir çok şeyi onlar bana öğtetiyorlar” dedi. Enstitü için yapılan bazı hizmetlerin parasını cebinden öder, ihtiyaçlı dunuma düşenlere maddî ve manevî yardımda bulunur. Kamu malını titizlikle korur. Enstitümüz'le ilgili işleri takip etmesine rağmen, şimdiye kadar bütçemizden ne yolluk-gündelik, ne de başka bir para kullanmışur. Ücretsiz bir tek fotokopi dahi çektimnez. Anlaşamadığımız bir tek nokta vardır: çok miktarda yazıyı imzaya götürdüğümüzde: "Bu ne kadar kàğıt israf ediyorsunuz?" diye, ciddî ciddî tenkit eder. Ben de: "Prosedür böyle ne yapalım?" diycrek geçiştiririm.

Uz. Alaattin UCA: 1992 yulinda açllan Atatürk Üniversitesi Türkiyat Araştırmalan Enstitüsü'nün diğer enstitüler gibi kendine ait bir binası olmadı̆g için birkaç yer değiştirdik. Sonunda Tip Fakültesi’nin üçüncü katında şimdiki yerimize taşındık. Burası hayli küçük, ihtiyaçlarımıza cevap vermiyor, hatta enstitümüz açıldı̆ğ günden beri müdürlük görevini yapan değerli hocamı, Profesör Doktor Efrasiyap GEMALMAZ'in makam odası bile yok. İşte böyle bir ortamda koridorun girișinde enstitü tabelâsı, teşhir dolabı ve ilan panomuz vardı. Bir gün aynı koridoru paylaştı̆̆ımız Enstitüden arkadaşlar bize gelerek girişteki tabelâ, teşhir dolabı ve panoyu kaldırmamızı ve kendilerinin yeni bir düzenleme yapacaklannı söylediler. Biz çok üzüldük yayınladığımı kitapları, dergileri nerede teşhir edecektik? Enstitü sekreterimiz de izinli olduğu için telefonla Hocamız'1 aradik: " Panomuzu girişteki yerinden alıp, içeride bir yere asmamızı istiyorlar, böyle şey olur mu, dergilerimizi kitaplarumızı kim görecek? " dedik. Hocamız bize şunları söyledi: "Bir Web sayfası oluşturun, yayınlarımızı internete geçelim. Böylece dünyaya açılalım, birkaç kişinin görmesiyle ne olacak?" $O$ günden sonra panomuza başka bir yer bulduk; ama, bizzat Hocamız'n teşvik ve yardımlan sayesinde internette "bttp://ataturkiyat0.tripod.com/" adresiyle bir de Web sayfamız oldu, böylece yayınlarımız sanal dünyadaki yerini aldı 